\title{
ネフェリンの熱膨張に及ぼすアルカリ及びアルカリ土類金属イオンの影響
}

\author{
太田敏孝・山井 䇻・張 申† \\ 名古屋工業大学工学部付属セラミックス研究施設, 507 岐阜県多治見市旭ケ丘 10-6-29
}

\section{Effect of Alkali and Alkaline Earth Metal lons on the Thermal Expansion of Nepheline}

Toshitaka OTA, Iwao YAMAI and Sheng ZHANG $^{\dagger}$

Ceramics Research Laboratory, Nagoya Institute of Technology, 10-6-29, Asahigaoka, Tajimi-shi

507

[Received November 6, 1992; Accepted January 29, 1993]

\begin{abstract}
Effects of alkali and alkaline earth metal ions on sintering and the thermal expansion behaviors of nepheline were investigated. Densification at lower sintering temperatures was promoted by $\mathrm{Li}_{2} \mathrm{CO}_{3}$ or $\mathrm{Na}_{2} \mathrm{CO}_{3}$ addition. The thermal expansion of nepheline decreased on substitution of $\mathrm{Li}^{+}$for $\mathrm{Na}^{+}$, and increased on substitution of $\mathrm{K}^{+}$for $\mathrm{Na}^{+}$. Nepheline solid solutions in the system $\mathrm{M}_{x} \mathrm{Na}_{1-x} \mathrm{AlSiO}_{4}(\mathrm{M}=\mathrm{Li}$ and $\mathrm{K})$ had mean axial thermal expansion coefficients ranging from $14 \times 10^{-6} /{ }^{\circ} \mathrm{C}$ to $20 \times 10^{-6} /{ }^{\circ} \mathrm{C}$ from room temperature to $1000^{\circ} \mathrm{C}$.
\end{abstract}

Key-words : Nepheline, High-thermal-expansion, $\mathrm{NaAlSiO}_{4}$, Solid-solution

\section{1. 緒 言}

一般にセラミックスは金属に比べて低い熱膨張を示す が，いくつかのケイ酸塩ではその $\alpha \rightarrow \beta$ 転移に伴い金属に 匹敵する高い熱膨張を示すことが知られている1) 4)。著 者らはこのうちシリカの詰め込み構造の一種である $\mathrm{NaAlSiO}_{4}$ を用い, その多形変態であるトリジマイト型ネ フェリンとクリストバライト型カーネギアイトからそれぞ れ約 $16 \times 10^{-6} /{ }^{\circ} \mathrm{C}$ 及び約 $15 \times 10^{-6} /{ }^{\circ} \mathrm{C}$ という従来にない高 い熱膨張係数を有するセラミックスを作製した ${ }^{5)}$ 。この值 は鉄系合金の $12 \sim 16 \times 10^{-6} /{ }^{\circ} \mathrm{C}$ ，ステンレス鋼の $12 \sim 19 \times$ $10^{-6} /{ }^{\circ} \mathrm{C}$ ，銅の $18 \times 10^{-6} /{ }^{\circ} \mathrm{C}$ な゙に匹敵し，これら金属と セラミックスとの複合材を作製する上で有用な材料となる ことが期待される.

天然においてはネフェリンはかすみ石として産出され， アルカリ成分としてその $1 / 4$ が $\mathrm{K} て ゙$ 置換された $\mathrm{KNa}_{3}$ $\left(\mathrm{AlSiO}_{4}\right)_{4}$ を基本組成とする6),7)。更にそのほかにも（K, $\mathrm{Na}, \mathrm{Ca}, \mathrm{Mg}, \mathrm{Fe}, \mathrm{Mn}, \mathrm{Ti})_{8}(\mathrm{Si}, \mathrm{Al}, \mathrm{Fe})_{16} \mathrm{O}_{32}$ で示されるよう な多くの構成元素を含む8)。これら天然のネフェリンの熱 膨張係数はその組成により多少異なり，16〜 $17 \times 10^{-6} /{ }^{\circ} \mathrm{C}$ の值が報告されている4). また,ネフェリンガラスセラミッ クスに拈いて $\mathrm{Na}^{+}$イオンの一部を $\mathrm{K}^{+}, \mathrm{Li}^{+}$あるは $\mathrm{Ca}^{2+}$ イオンによって置換した場合，熱膨張係数が6〜 $13 \times 10^{-6} /{ }^{\circ} \mathrm{C}$ と大き変化することが報告されている ${ }^{9)}$. したがって，ネフェリンに他の元素を添加することによっ

\footnotetext{
†現在: 中国科学院上海硅酸塩研究所, 上海200050, 中国. Present address: Shanghai Institute of Ceramics, Chinese Academy of Sciences, Shanghai 200050, P. R. China.
}

て熱膨張を制御し，種々の金属に一致する熱膨張係数を有 する高熱膨張性セラミックスが作製できると考えられる。 そこで本報告では, 特にアルカリ及びアルカリ土類金属イ オンによるネフェリンセラミックスの熱膨張への影響につ いて，その焼結挙動への影響も含め詳細に検討した。

\section{2. 実験方法}

純 $\mathrm{Na}$ ネフェリン $\left(\mathrm{NaAlSiO}_{4}\right)$ は, 市販試薬（和光純 薬工業製）の無水炭酸ナトリウム $\left(\mathrm{Na}_{2} \mathrm{CO}_{3}\right)$, 活性アルミ ナ $\left(\mathrm{Al}_{2} \mathrm{O}_{3}\right)$ 及び二酸化ケイ素 $\left(\mathrm{SiO}_{2}\right)$ をモル比で $1: 1$ : 2 の割合に秤量し，アルミナ製自動乳鉢で 4 時間乾式混合 後, $850^{\circ} \mathrm{C}$ で脱炭酸を行い, $1200^{\circ} \mathrm{C}$ に 4 時間焼成するこ とにより合成した． $\mathrm{Li}^{+}$及び $\mathrm{K}^{+}$イオンを固溶したネフェ リンの場合, $\mathrm{Na}_{2} \mathrm{CO}_{3}$ の一部を $\mathrm{Li}_{2} \mathrm{CO}_{3}$ あるいは $\mathrm{K}_{2} \mathrm{CO}_{3}$ に より置換することにより同様にして合成した。

結晶の熱膨張は，粉末 X 線回折装置（島津製作所製， COMPAX) に高温加熱装置（島津製作所製，HX-3）を 取り付け，室温から $1000^{\circ} \mathrm{C}$ での格子定数を測定するこ とにより行った. 各温度の格子定数は $2 \theta=20^{\circ} \sim 50^{\circ}(\mathrm{Cu}$ $\mathrm{K} \alpha$ ）の範囲のピークを用いて, UNICS-RSLC3プログラ ムにより計算した。ピーク位置は内部標準として白金で補 正した。そして，各温度の格子定数を 2 次式で回帰して 熱膨張曲線とした。

焼結は合成した原料粉末に添加剂として $\mathrm{Li}_{2} \mathrm{CO}_{3}, \mathrm{Na}_{2} \mathrm{CO}_{3}$, $\mathrm{K}_{2} \mathrm{CO}_{3}, \mathrm{CaCO}_{3}$ 及び $\mathrm{MgO}$ を 0 5 wt\%加え, 直径 $16 \mathrm{~mm} \times$ 厚さ $4 \mathrm{~mm}$ のペレット及び $60 \times 5 \times 5 \mathrm{~mm}$ の直方体に 100 $\mathrm{MPa}$ で一軸加圧成形し， $1100 \sim 1250^{\circ} \mathrm{C}$ にて 2 時間行っ た. 試料が高膨張であることから冷却は $50 \sim 100^{\circ} \mathrm{C} / \mathrm{h}$ の速 度で行った. 得られた焼結体のかさ密度はアルキメデス法 によって測定した．強度はオートグラフ（島津製作所製, S-500）を用いて 3 点曲げ試験により測定した。熱膨張は シリカガラス製押し棒式熱膨張計（島津製作所製, TMA30）を用いて，室温から $750^{\circ} \mathrm{C}$ を゙昇温速度 $10^{\circ} \mathrm{C} /$ min で測定した。 また, 焼結体の微構造を走査型電子顕微 鏡 $(\mathrm{SEM}$ : 日本電子製, JSM-T20）により観察した。

\section{3. 結果及び考察}

3.1 アルカリ及びアルカリ土類金属イオンの添加によ るネフェリンセラミックスの作製とその熱膨張 
はじめにアルカリ及びアルカリ土類金属イオンを炭酸塩 あるいは酸化物の形で $\mathrm{NaAlSiO}_{4}$ 原料粉末に添加して，そ の焼結挙動及び熱膨張への影響について検討した。ネフェ

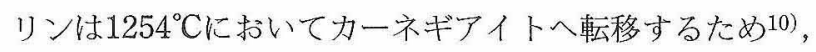
$1250^{\circ} \mathrm{C}$ な゙の温度にて焼結を行った。図1は，各々の添 加剤をネフェリンの0〜 0 wt\%の割合で混合した粉末成形 体の焼結温度によるかさ密度の变化を示す。無添加試料の 場合, 焼結温度の増加とともにかさ密度は増加し, $1250^{\circ} \mathrm{C}$, 2 時間の焼結で約 $90 \%$ の相刘密度に到達した。 $\mathrm{Li}_{2} \mathrm{CO}_{3}$ め るいは $\mathrm{Na}_{2} \mathrm{CO}_{3}$ を添加した場合, 無添加の場合に比べ低温 で緻密化した． $\mathrm{Li}_{2} \mathrm{CO}_{3} 5 \mathrm{wt} \%$ 添加試料では $1150^{\circ} \mathrm{C}$ で相対 密度約 $87 \%$ となった。しかし，それ以上の焼結温度では 溶融した。市， $\mathrm{Na}_{2} \mathrm{CO}_{3} 5 \mathrm{wt} \%$ 及び $\mathrm{Li}_{2} \mathrm{CO}_{3} 2 \mathrm{wt} \%$ 添加 試料は $1250^{\circ} \mathrm{C}$ 焼結では無添加の場合とほぼ同じ密度で めった． $\mathrm{K}_{2} \mathrm{CO}_{3}$ を添加した場合，焼結は抑制され $1250^{\circ} \mathrm{C}$ に抢いても約 $80 \%$ の相対密度までしか緻密化しなかっ た. $\mathrm{CaCO}_{3}$ を添加した場合は無添加と全く同様の緻密化 挙動を示した。をた，MgOを添加した場合，ほとんど緻 密化は進行しなかった。粉末 X 線回折の結果, $\mathrm{MgO}$ 添加 の場合， $1200^{\circ} \mathrm{C}$ 焼結に扝いて既にカーネギアイトが生

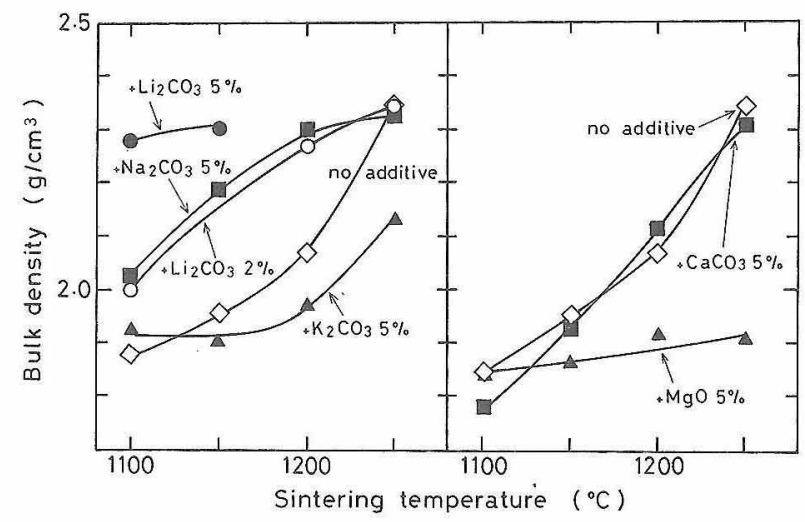

Fig. 1. Bulk density of nepheline vs. sintering temperature fired with and without additives.
成していることが確認された。したがって，これが緻密化 しなかった原因の一つで山ると考えられる。なお， $\mathrm{MgO}$ 添加以外の試料では $1250^{\circ} \mathrm{C}$ な゙の焼結温度に扔いてカ一 ネギアイトは生成しなかった。

図 2 は代表的な焼結試料の SEM 写真を示す. 前報5)で 示したように，ネフェリンの焼結は一般のケイ酸塩系セラ ミックスと同様, 液相の存在による緻密化が支配的である と考えられる。無添加試料の場合, $1100^{\circ} \mathrm{C} の$ 低温におい ては図 2 (a)に示されるような部分的な融着は起きたが全 体的な緻密化には至らなかった。一方, $\mathrm{Li}_{2} \mathrm{CO}_{3}$ 及び $\mathrm{Na}_{2} \mathrm{CO}_{3}$ 添加試料の場合，図 2 (b)に示されるように全体的に均一 な融着が起き，これが低温で緻密化した原因と考えられ る。この試料をHFによりエッチングした結果，液相が 除かれ図 2 (c)に示されるような密に詰まった結晶粒子が 現れた。高温では無添加, ならびに $\mathrm{Li}_{2} \mathrm{CO}_{3}, \mathrm{Na}_{2} \mathrm{CO}_{3}$ 及び $\mathrm{CaCO}_{3}$ 添加いずれの試料も全体に液相が覆った一様なマ トリックス中に，大きな気孔が散在した図 2 (d)及び(e) に示されるような微構造を示した.このような閉気孔がいっ たん形成されるとその除去は非常に困難となるため，いず れの添加試料に扮いても同様の状態となり，相刘密度とし ては $90 \%$ 以上緻密化しなかったと考えられる. また， $\mathrm{K}_{2} \mathrm{CO}_{3}$

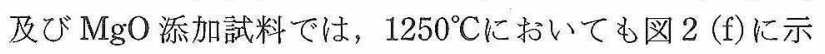
されるように，図2 (d)及び(e)のよう結晶粒子全体を 覆うような液相の形成は観察されず，このため緻密化しな かったと考えられる.

図 3 は各添加剂を $5 \mathrm{wt} \%$ 添加した焼結試料の熱膨張曲 線を示す。 $\mathrm{Na}_{2} \mathrm{CO}_{3}$ 添加の場合は無添加とほとんど同じ で, その熱膨張係数は室温から $750^{\circ} \mathrm{C}$ 範囲で約 $16 \times 10^{-6} /{ }^{\circ} \mathrm{C}$ でせった. $\mathrm{Li}_{2} \mathrm{CO}_{3}$ 及び $\mathrm{CaCO}_{3}$ 添加の場合は無添加に比べ

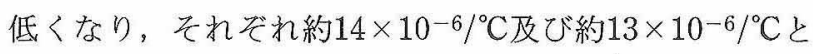
なった。一方, $\mathrm{K}_{2} \mathrm{CO}_{3}$ 添加の場合は $17 \times 10^{-6} /{ }^{\circ} \mathrm{C}$ 高くなっ た. また, $\mathrm{MgO}$ 添加の場合, 約 $600^{\circ} \mathrm{CK}$ 急激な膨張が認 められた。これはカーネギアイト相の $\alpha \rightarrow \beta$ 転移による影 響と考えられるが，その転移温度は純 $\mathrm{Na}$ ネフェンに比
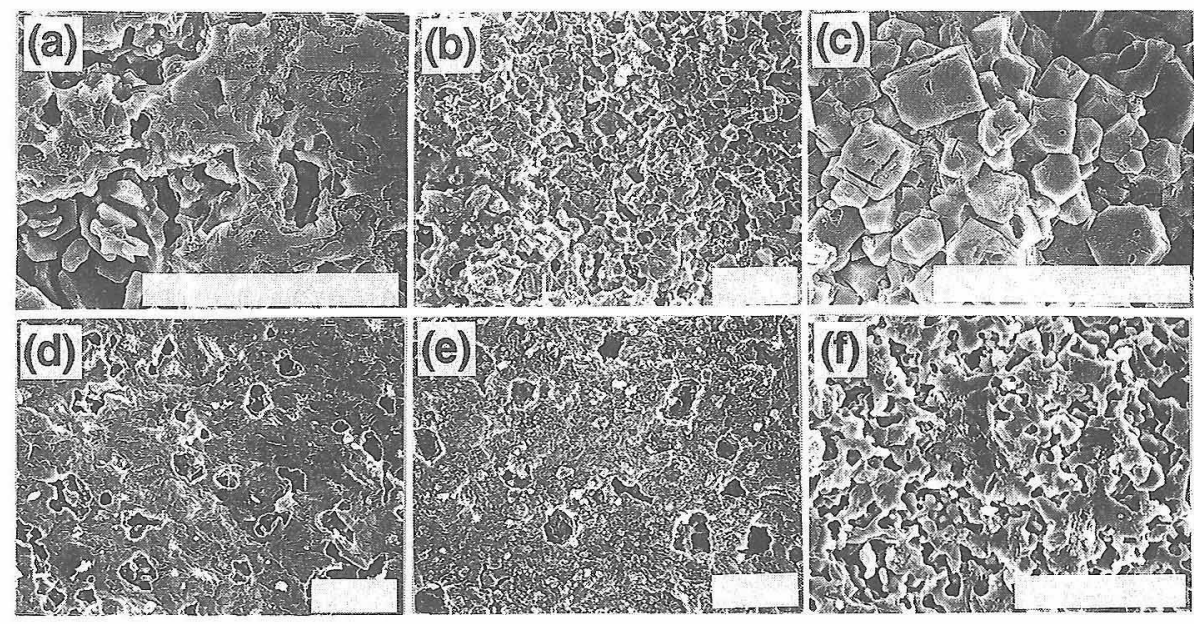

Fig. 2. SEM photographs of fracture surfaces of nepheline ceramics sintered (a) to (c) at $1100^{\circ} \mathrm{C}$ and (d) to (f) at $1250^{\circ} \mathrm{C}$; (a) and (d) with no additive, (b) and (c) respective with $5 \mathrm{wt} \% \mathrm{Li}_{2} \mathrm{CO}_{3}$, (e) with $5 \mathrm{wt} \% \mathrm{Na}_{2} \mathrm{CO}_{3}$, and (f) with $5 \mathrm{wt} \% \mathrm{MgO}$. (bar $\left.=50 \mu \mathrm{m}\right)$. 


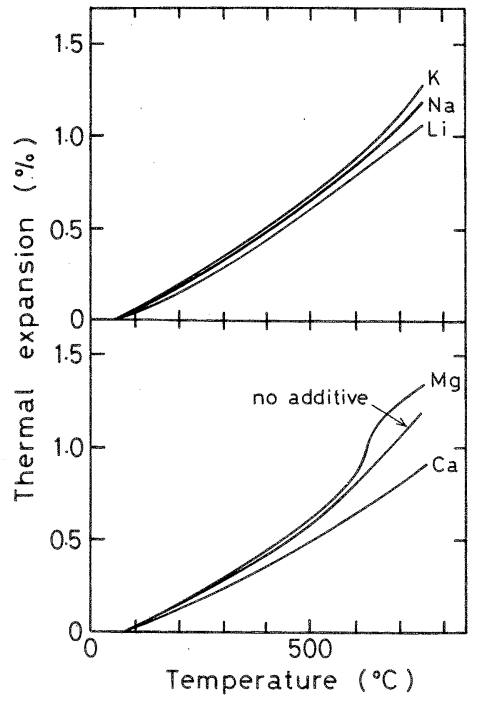

Fig. 3. Changes in thermal expansion curves of nepheline ceramic sintered with and without additives.

べ約 $100^{\circ} \mathrm{C}$ 低下した. 以上の結果は, 緒言で述べたように ネフェリン結晶への各々のイオンの固溶が原因と考元られ た。 そこで次に, 特に $\mathrm{Li}^{+}$及び $\mathrm{K}^{+}$イオンのネフェリン結 晶への固溶について検討した.

3.2 アルカリイオンの固溶によるネフェリン結晶の熱 膨張の変化

$\mathrm{Na}_{2} \mathrm{CO}_{3}$ を $\mathrm{Li}_{2} \mathrm{CO}_{3}$ あるいは $\mathrm{K}_{2} \mathrm{CO}_{3}$ により種々の割合で 置換してネフェリン固溶体の合成を行った。その結果, $\mathrm{Li}$ 系の場合 $\mathrm{M}_{x} \mathrm{Na}_{1-x} \mathrm{AlSiO}_{4}$ として $x=0.2$ まで, $\mathrm{K}$ 系の場 合天然のネフェリン $\left(\mathrm{KNa}_{3}\left(\mathrm{AlSiO}_{4}\right)_{4}\right)$ と一致する $x=0.25$ まで単一相として生成した。この固溶量はネフェ リンガラスセラミックスの場合9) と一致した. 得られた固 溶体結晶の $x$ による格子定数の変化を図 4 に示す. $\mathrm{Li}$ 系 の場合, $a$ 軸も $c$ 軸も $x=0$ の純 $\mathrm{Na}$ ネフェリンからほとん ど変化しなかったが，K 系の場合 $a$ 軸及び $c$ 軸共その固溶

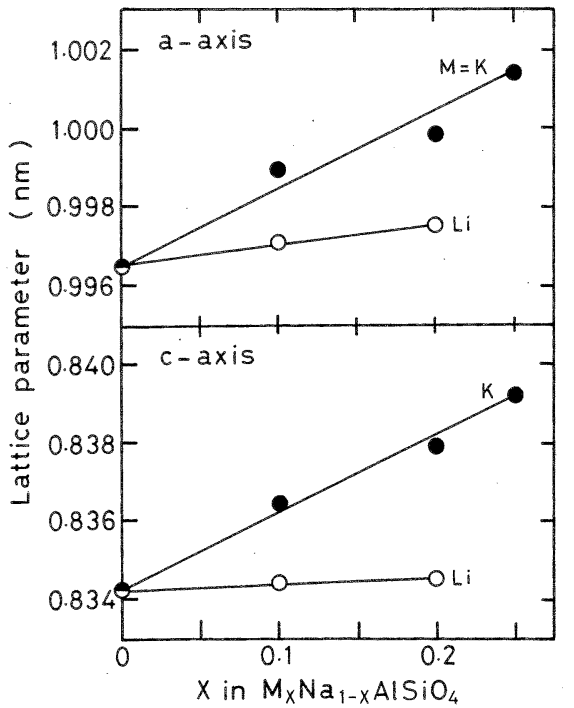

Fig. 4. Lattice parameters vs. composition $(x)$ for nepheline solid solutions.
量の増加につれて増加した。ネフェリンの結晶構造におい てアルカリイオンは (A1, $\mathrm{Si}) \mathrm{O}_{4}$ 四面体で形成される歪ん だ六員環の空隙を占める11)。天然ネフェリン結晶 $\left(\mathrm{KNa}_{3}\right.$ $\left.\left(\mathrm{AlSiO}_{4}\right)_{4}\right)$ ではこの歪んだ六員環は大きな $\mathrm{K}^{+}$イオンに よって広げられほぼ正六角形となる7)。その結果，格子定 数は増加する。一方，小さい $\mathrm{Li}^{+}$イオンはこの六員環を 広げないため格子定数の変化を生じなかったと考元られ る.

図 5 及び図 6 はそれぞれ $\mathrm{Li}^{+}$及び $\mathrm{K}^{+}$イオンを固溶し たネフェリン結晶格子の温度変化を示す。いずれの組成も 純 $\mathrm{Na}$ ネフェリンと同様，ほぼ直線的に大きく変化した。 これらの結果から算出した室温から $1000^{\circ} \mathrm{C}$ ま゙の平均線 熱膨張係数を図 7 に示す. $\mathrm{Li}$ 系固溶体の場合，固溶量の 増加により $a$ 軸も $c$ 軸も共にその熱膨張係数は低下し， $x=0.2$ でその平均は約 $14 \times 10^{-6} /{ }^{\circ} \mathrm{C}$ となった。 $\mathrm{K}$ 系固溶体 の場合， $x$ の増加により $a$ 軸の熱膨張係数は大きくなった が $c$ 軸はほとんど変化しなかった。そして $x=0.25$ の $\mathrm{KNa}_{3}\left(\mathrm{AlSiO}_{4}\right)_{4}$ 結晶の平均の熱膨張係数は約 $20 \times 10^{-6} /{ }^{\circ} \mathrm{C}$ であった。この值は天然のネフェリンについて報告されて いる $\left.16 \sim 17 \times 10^{-6} /{ }^{\circ} \mathrm{C} 4\right)$ に比べはるかに大きかった。これ は，天然には3.1節で示したような熱膨張を低下させる $\mathrm{Ca}^{2+}$ イオンも比較的多量に含まれているためであると考 えられる。
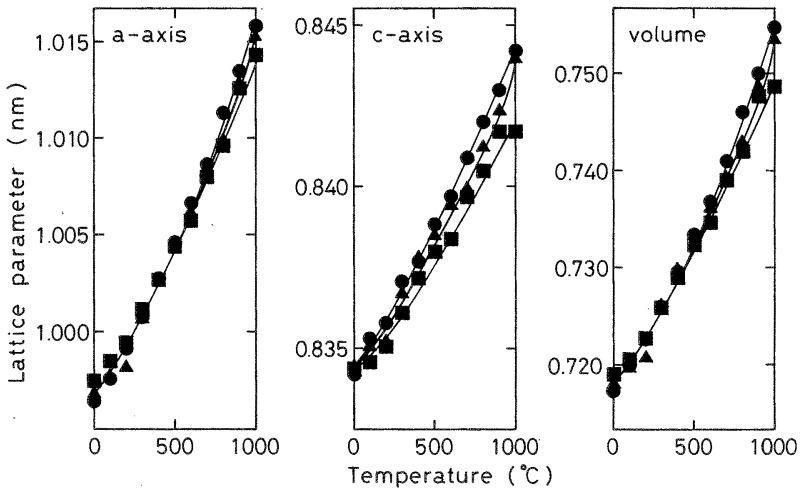

Fig. 5. Lattice parameters of $\mathrm{Li}_{x} \mathrm{Na}_{1-x} \mathrm{AlSiO}_{4}$ vs. temperature. $: x=0, \boldsymbol{\Delta}: x=0.1, \mathbf{\square}: x=0.2)$.
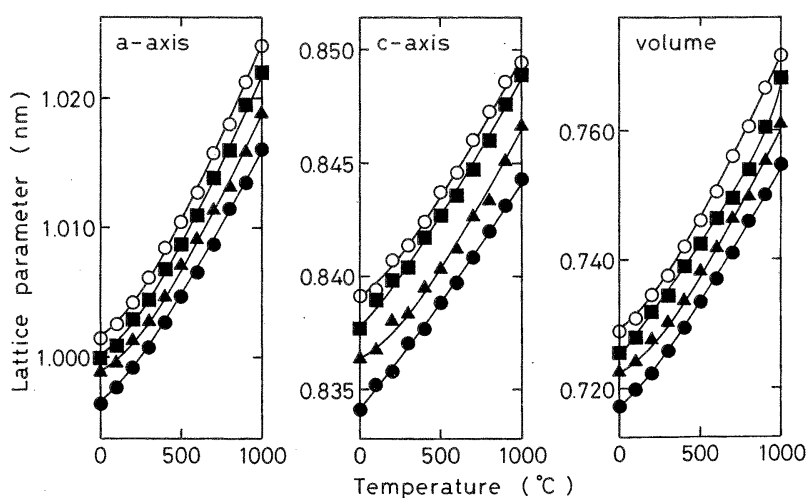

Fig. 6. Lattice parameters of $\mathrm{K}_{x} \mathrm{Na}_{1-x} \mathrm{AlSiO}_{4} \mathrm{vs}$. temperature.

$(\mathbf{O}: x=0, \boldsymbol{\Delta}: x=0.1, \mathbf{\square}: x=0.2, \bigcirc: x=0.25)$. 


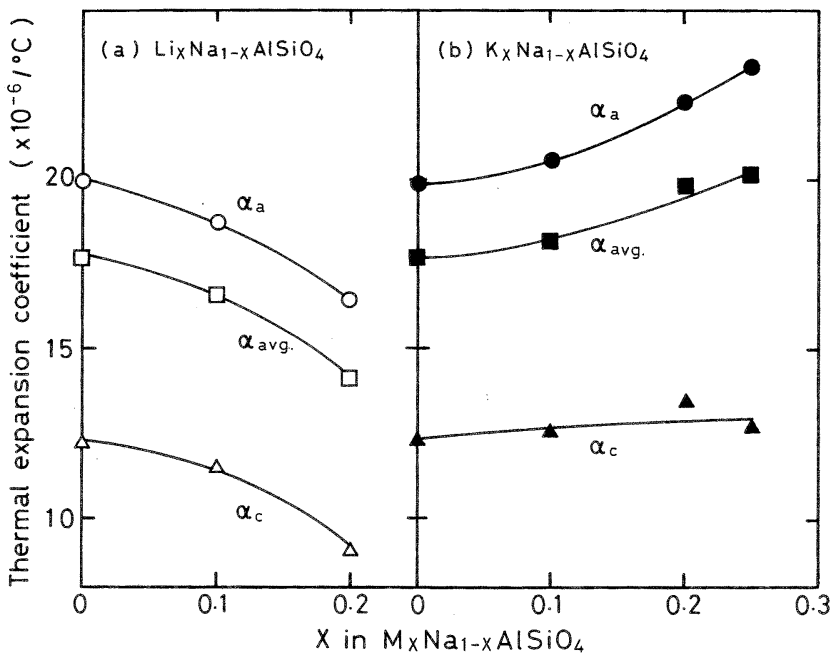

Fig. 7. Mean linear thermal expansion coefficient from room temperature to $1000^{\circ} \mathrm{C}$ vs. composition $(x)$ for nepheline solid solutions.

以上の $\mathrm{Li}^{+}$及び $\mathrm{K}^{+}$イオンのネフェリン結晶への固溶 による熱膨張の減少及び増加は, 3.1 節に述べた $\mathrm{Li}_{2} \mathrm{CO}_{3}$ あ るいは $\mathrm{K}_{2} \mathrm{CO}_{3}$ を添加して焼結したネフェリンセラミック スの熱膨張の変化と一致した．なお，それら焼結体の熱膨 張係数, $14 \times 10^{-6} /{ }^{\circ} \mathrm{C}$ 及び $17 \times 10^{-6} /{ }^{\circ} \mathrm{C}$ と, $\mathrm{M}_{x} \mathrm{Na}_{1-x} \mathrm{AlSiO}_{4}$ 固溶体結晶格子の室温加 $750^{\circ} \mathrm{C}$ までの平均線熱膨張係数 との比較から，焼結体中における $\mathrm{Li}^{+}$及び $\mathrm{K}^{+}$イオンの ネフェリンへの固溶量は, それぞれ約 $x=0.15$ 及び 0.1 と推 定された。 $\mathrm{Li}_{2} \mathrm{CO}_{3}$ 及び $\mathrm{K}_{2} \mathrm{CO}_{3}$ が純 $\mathrm{Na}$ ネフェリンに対し $5 \mathrm{wt} \%$ 添加されたとき， $\mathrm{Li}^{+}$及び $\mathrm{K}^{+}$イオンがすべて $\mathrm{Na}^{+}$ イオンと置換した場合, それらの固溶量は $x=0.16$ 及び 0.09 と計算される．したがって，3.1節に述べた焼結体中 では, 添加された $\mathrm{Li}_{2} \mathrm{CO}_{3}$ 及び $\mathrm{K}_{2} \mathrm{CO}_{3}$ 中の $\mathrm{Li}^{+}$及び $\mathrm{K}^{+}$ は, ほとんどすべて $\mathrm{Na}^{+}$イオンと置換してネフェリン結 晶へ固溶したと考えられる。

\section{4. 総 括}

$\mathrm{NaAlSiO}_{4}$ ネフェリンにアルカリ及びアルカリ土類金属 イオンを添加することにより，その焼結挙動及び熱膨張特 性が変化した. $\mathrm{Li}_{2} \mathrm{CO}_{3}$ 及び $\mathrm{Na}_{2} \mathrm{CO}_{3}$ の添加は低温での緻 密化を促進した。熱膨張は $\mathrm{Li}_{2} \mathrm{CO}_{3}$ 及び $\mathrm{CaCO}_{3}$ の添加に より低下し， $\mathrm{K}_{2} \mathrm{CO}_{3}$ の添加により高くなった。また， $\mathrm{MgO}$ の添加はネフェリンの多形変態であるカーネギアイ ト化を促進した。これらは各イオンがネフェリンに固溶す るためと考えられた。

$\mathrm{M}_{x} \mathrm{Na}_{1-x} \mathrm{AlSiO}_{4}$ の $\mathrm{M}^{+}$イオンは, $\mathrm{Li}^{+}$イオンの場合 0.20 屯で, $\mathrm{K}^{+}$イオンの場合 0.25 まで固溶した。これら固 溶体結晶の熱膨張係数は, 室温か $51000^{\circ} \mathrm{C}$ ま゙の平均で それぞれ約 $14 \times 10^{-6} /{ }^{\circ} \mathrm{C}$ 及び約 $20 \times 10^{-6} /{ }^{\circ} \mathrm{C}$ であった。し たがって，固溶イオンの種類及び固溶量を変化させること によってネフェリンの熱膨張を広範囲にわたり変化させる ことが可能であると考えられる。これはセラミックスの熱 膨張係数を鉄，ステンレス，銅等主な金属に一致させるこ とができることを意味し，金属一セラミックス複合材の作 製において非常に有用と考えられる。

\section{文献}

1) D. Taylor, Mineral. Mag., 38, 593-604 (1972).

2) D. Taylor and C. M. B. Henderson, Am. Mineral., 53, 147689 (1968).

3) D. Taylor, Mineral. Mag., 36, 761-69 (1968).

4) G. Sahama, J. Petrol., 3, 65-81 (1962).

5) 太田敏孝, 山井 巌, 張 申, J. Ceram. Soc. Japan, 100, 1361-65 (1992).

6) M. J. Buerger, Am. Mineral., 39, 600-14 (1954).

7）桐山良一, “構造無機化学 III", 共立出版 (1978) p. 216.

8) G. Donnay, J. F. Schairer and J. D. H. Donnay, Mineral. Mag., 32, 93-109 (1959).

9) J. F. MacDowell, Am. Ceram. Soc. Bull., 63, 282-86 (1984).

10) W. A. Deer, R. A. Howie and J. Zussman, "Rock Forming Minerals, Vol. 4, Framework Silicates”, Longmans (1963) pp. 231-70.

11) M. J. Buerger, G. Kliein and G. Donnay, Am. Mineral., 39, 805-18 (1954). 